\title{
Meeting the Sustainable Development Goal of Good Health and Well-Being by European Union Countries in 2017
}

\author{
Iwona Konarzewska \\ Ph.D., Assistant Professor, University of Lodz, Lodz, Poland \\ e-mail: iwona.konarzewska@uni.lodz.pl
}

\begin{abstract}
In September 2015, the United Nations General Assembly adopted the 2030 Agenda for Sustainable Development, which includes 17 Sustainable Development Goals (SDGs). One of them, Goal 3, is defined as: Ensure healthy lives and promote well-being for all at all ages. In the paper, we have considered the indices proposed by Eurostat, which help to measure the level that the targets achieve. We present the dynamics of indices over the period 2002-2017. Multi-criteria statistical analysis for 28 EU countries was conducted using data up to 2017 to show how much EU countries are diversified and to present rankings of countries on their way to achieving the good health and well-being status of their citizens. The results are compared with a global SGD-Sub-Index for Goal 3, developed by Sachs et al. (2018).
\end{abstract}

Keywords: SDG, multi-criteria rankings, health and well-being

JEL: C44, I31 


\section{Introduction}

In September 2015, the United Nations General Assembly adopted the 2030 Agenda for Sustainable Development ${ }^{1}$ that includes 17 Sustainable Development Goals (SDGs) ${ }^{2}$. Among them, we can find: end poverty, end hunger, ensure healthy lives, promote well-being for all at all ages, equitable quality education, achieve gender equality, make water available for all, promote sustainable economic growth, modern energy, sustainable consumption, and combat climate change.

For each of the SDGs, between five and nineteen targets were formulated.

McGillivray and Noorbakhsh (2004) surveyed the various composite well-being indices developed over recent years, including the well-known Human Development Index (HDI). They present a critical view of the criteria and structure of the indices as well as give recommendations for future work on measuring well-being.

For sustainable development Goal 3, which is of particular interest to us in this work, the UN formlated the following thirteen targets to be achieved by $2030^{3}$ :

T1. Reduce the global maternal mortality ratio to less than 70 per 100,000 live births.

T2. End preventable deaths of newborns and children under five years of age, with all countries aiming to reduce neonatal mortality to at least as low as 12 per 1,000 live births and under-5 mortality to at least as low as 25 per 1,000 live births.

T3. End the epidemics of AIDS, tuberculosis, malaria, and neglected tropical diseases and combat hepatitis, water-borne diseases and other communicable diseases

T4. Reduce by one-third premature mortality from non-communicable diseases through prevention and treatment, and promote mental health and well-being.

T5. Strengthen the prevention and treatment of substance abuse, including narcotic drug abuse and harmful use of alcohol.

T6. By 2020, halve the number of global deaths and injuries from road traffic accidents

T7. Ensure universal access to sexual and reproductive health-care services, including for family planning, information and education, and the integration of reproductive health into national strategies and programmes.

T8. Achieve universal health coverage, including financial risk protection, access to quality essential health-care services, and access to safe, effective, quality, and affordable essential medicines and vaccines for all.

T9. Substantially reduce the number of deaths and illnesses from hazardous chemicals and air, water, and soil pollution and contamination.

T10. Strengthen the implementation of the World Health Organization Framework Convention on Tobacco Control in all countries, as appropriate.

1 "Transforming our world ..." Resolution of UN General Assebly. September 2015.

2 https://www.un.org/sustainabledevelopment/sustainable-development-goals/ (accessed: 31.08 .2019 )

3 https://www.un.org/sustainabledevelopment/sustainable-development-goals/ (accessed: 31.08.2019) 
T11. Support the research and development of vaccines and medicines for the communicable and noncommunicable diseases that primarily affect developing countries, and provide access to affordable essential medicines and vaccines. ${ }^{4}$

T12. Substantially increase health financing and the recruitment, development, training, and retention of the health workforce in developing countries, especially in least developed countries and small island developing States.

T13. Strengthen the capacity of all countries, in particular developing countries, for early warning, risk reduction, and management of national and global health risks.

The recent comprehensive research results for the OECD approach for measuring well-being in 36 countries who are members of OECD can be found in the OECD (2017). In our research, to measure the level of "healthy" and "well-being," we use indicators developed by EUROSTAT, which are defined as follows"

I1. Life expectancy at birth by sex [SDG_03_10]. Life expectancy at birth is defined as the mean number of years that a new-born child can expect to live if subjected throughout his life to the current mortality conditions (age-specific probabilities of dying).

I2. Share of people with good or very good perceived health by sex [SDG_03_20]. The indicator is a subjective measure of how people judge their health in general on a scale from "very good" to "very bad." It is expressed as the share of the population aged 16 or over perceiving themselves to be in "good" or "very good" health. The data stem from the EU Statistics on Income and Living Conditions (EU SILC). Indicators of perceived general health have been found to be a good predictor of people's future health care use and mortality.

I3. Smoking prevalence by sex (source: DG SANTE) [SDG_03_30]. The indicator measures the share of the population aged 15 years and over who report that they currently smoke boxed cigarettes, cigars, cigarillos, or a pipe. The data do not include the use of other tobacco products, such as electronic cigarettes and snuff. The data are collected through a Eurobarometer survey and are based on self-reports during face-to-face interviews in people's homes.

I4. Death rate due to chronic diseases by sex [SDG_03_40]. The indicator measures the standardized death rate ${ }^{6}$ of chronic diseases ${ }^{7}$. Death due to chronic diseases is considered premature if it occurs before the age of 65 . The rate is calculated by dividing the number of people under 65 dying due to chronic disease by the

4 In accordance with the Doha Declaration on the TRIPS Agreement and Public Health (November 2001), which affirms the right of developing countries to use the full the provisions in the Agreement on Trade Related Aspects of Intellectual Property Rights regarding flexibilities to protect public health, and, in particular, provide access to medicines for all.

5 https://ec.europa.eu/eurostat/web/sdi/main-tables (accessed: 31.08.2019) All consecutive explanations in the text follow definitions presented by EUROSTAT.

6 The data are presented as standardized death rates, comparable over time and between countries.

7 International Classification of Diseases (ICD) codes C00 to C97, E10 to E14, I20 to I25, I60 to I69 and $\mathrm{J} 40$ to $\mathrm{J} 47$. 
total population under 65 . Unit of measurement: number per 100,000 people aged less than 65 by sex.

I5. Death rate due to tuberculosis, HIV, and hepatitis by sex [SDG_03_41]. The indicator measures the standardized death rate $^{8}$ of tuberculosis, HIV, and hepatitis ${ }^{9}$ The rate is calculated by dividing the number of people dying due to selected communicable diseases by the total population. Unit of measurement: number per 100,000 people.

I6. Self-reported unmet need for medical examination and care by sex [SDG_03_60]. The indicator measures the share (\%) of the population aged 16 and over who report unmet needs for medical care due to one of the following reasons: 'Financial reasons,' 'Waiting list,' and 'Too far to travel' (all three categories are cumulated). Self-reported unmet needs concern a person's own assessment of whether he or she needed medical examination or treatment (dental care excluded), but did not have it or did not seek it. The data stem from the EU Statistics on Income and Living Conditions (EU SILC). ${ }^{10}$

I7. Obesity rate by body mass index (BMI) [SDG_02_10]. The indicator measures the share of obese people based on their body mass index (BMI). BMI is defined as the weight in kilos divided by the square of the height in meters. People aged 18 years or over are considered obese with a BMI equal to or greater than 30 . Other categories are: underweight (BMI less than 18.5), normal weight (BMI between 18.5 and less than 25), and pre-obese (BMI between 25 and less than 30). The overweight category (BMI equal to or greater than 25) combines two categories, pre-obese and obese.

I8. People killed in accidents at work [SDG_08_60]. The indicator measures the number of fatal accidents that occur during the course of work and which lead to the death of the victim within one year of the accident. The incidence rate refers to the number of fatal accidents per 100,000 people in employment.

19. Population living in households considering that they suffer from noise, by poverty status [SDG_11_20]. The indicator measures the proportion of the population who declare $^{11}$ that they are affected either by noise from neighbors or from the street.

8 As explained in target 4.

9 International Classification of Diseases (ICD) codes A15-A19_B90, B15-B19_B942 and B20-B24.

10 Note on the interpretation: "The indicator is derived from self-reported data so it is, to a certain extent, affected by respondents' subjective perception as well as by their social and cultural background. Another factor playing a role is the different organization of health care services, be that nationally or locally. All these factors should be taken into account when analyzing the data and interpreting the results."

11 "Because the assessment of noise pollution is subjective, it should be noted that the indicator accounts for both the levels of noise pollution as well as people's standards of what level they consider to be acceptable. Therefore, an increase in the value of the indicator may not necessarily indicate a similar increase in noise pollution levels but also a decrease of the levels that European citizens are willing to tolerate and vice versa. In fact, there is empirical evidence that perceived environmental quality by individuals is not always consistent with the actual environmental quality assessed using 'objective' indicators, particularly for noise." 
I10. People killed in road accidents ${ }^{12}$ [SDG_11_40]. The indicator measures the number of fatalities caused by road accidents, including drivers and passengers of motorized vehicles and pedal cycles, as well as pedestrians. People who die in road accidents up to 30 days after the occurrence of the accident are counted as road accident fatalities. After the 30 days, the reason for dying might be declared differently. For the Member States that do not use this definition, corrective factors were applied. The average population of the reference year (calculated as the arithmetic mean of the population on $1^{\text {st }}$ January of two consecutive years) is used as the denominator (per 100,000 people).

11. Exposure to air pollution by particulate matter ${ }^{13}$ [SDG_11_50a and SDG_11_50b]. The two formulated indicators measure the population-weighted annual mean concentration, in $\mu \mathrm{g} / \mathrm{m}^{3}$, of particulate matter - PM10 and PM2.5 - at urban background stations in agglomerations. ${ }^{14}$ The WHO guideline value for PM2.5 is to reduce its concentration to $10 \mu \mathrm{g} / \mathrm{m}^{3}$ in 2020 .

The choice of indicators does not cover the ability to measure the achievement of all 13 formulated targets. For instance, instead of indicators of maternal and neonatal mortality, EUROSTAT measures life expectancy at birth. Neither indicator measures how much effort is made to prevent narcotic drug and alcohol abuse; only smoking prevalence is considered. Universal health coverage is represented by the self-reported indicator of unmet needs for medical examination and care. The types of pollution considered are air pollution by particulate matters and the subjective perception of noise.

\section{Main trends observed in the indices of Goal 3: Ensure healthy lives and promote well-being for all at all ages}

Life expectancy continuously increased from 77.7 in 2002 to 81 years in 2016. In 2017, it decreased slightly to 80.9 years - see Fig. 1. An interesting indicator is SDG3.20, which monitors subjective perceptions of good health. It shows that starting in 2015, EU citizens each year feel better. Other indicators show that exposure to unhealthy lifestyles in the $\mathrm{EU}$ is, in general, decreasing. A worrying problem is exposure to air pollution - as shown in Fig. 3 and Fig. 4 for PM10 and PM2.5, respectively. For PM2.5, it increased in 2017 to $14.1 \mu \mathrm{g} / \mathrm{m}^{3}$ from $13.8 \mu \mathrm{g} / \mathrm{m}^{3}$ observed in 2016 - the WHO goal to reduce this value below $10 \mu \mathrm{g} / \mathrm{m}^{3}$ seems to be unachievable.

12 DG MOVE - The European Commission's Directorate-General for Mobility and Transport.

EEA - European Environment Agency.

14 "Fine and coarse particulates (PM10), i.e. particulates whose diameters are less than 10 micrometers, can be carried deep into the lungs where they can cause inflammation and exacerbate the condition of people suffering heart and lung diseases. Fine particulates PM2.5 are those whose diameters are less than 2.5 micrometers. They are therefore a subset of the PM10 particles. Their deleterious health impacts are more serious than PM10 as they can be drawn further into the lungs and may be more toxic." 


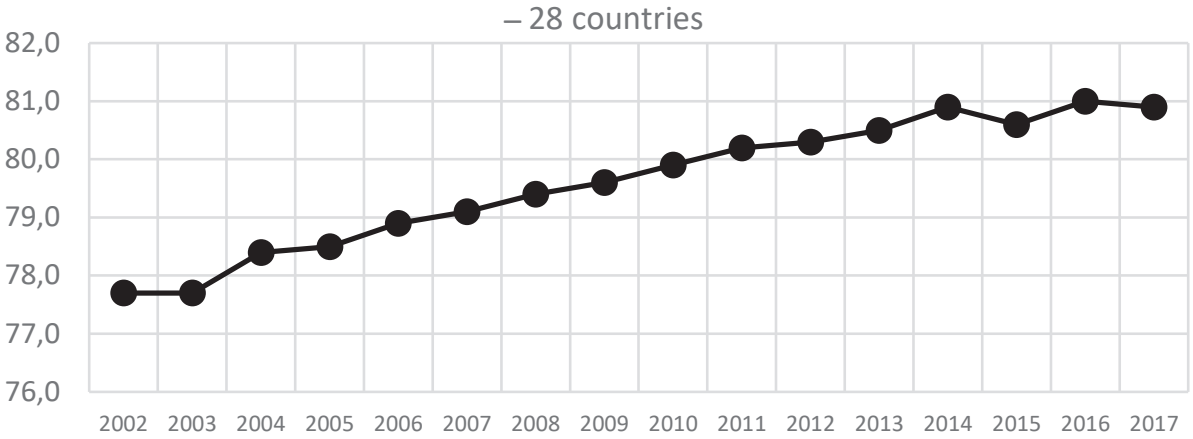

Figure 1. Life expectancy at birth in years - the mean values for 28 European countries Source: own calculations based on data from https://ec.europa.eu/eurostat/web/sdi/main-tables (accessed: 31.08.2019)

Share of people with good or very good perceived health - total [SDG_03_20]-28 countries

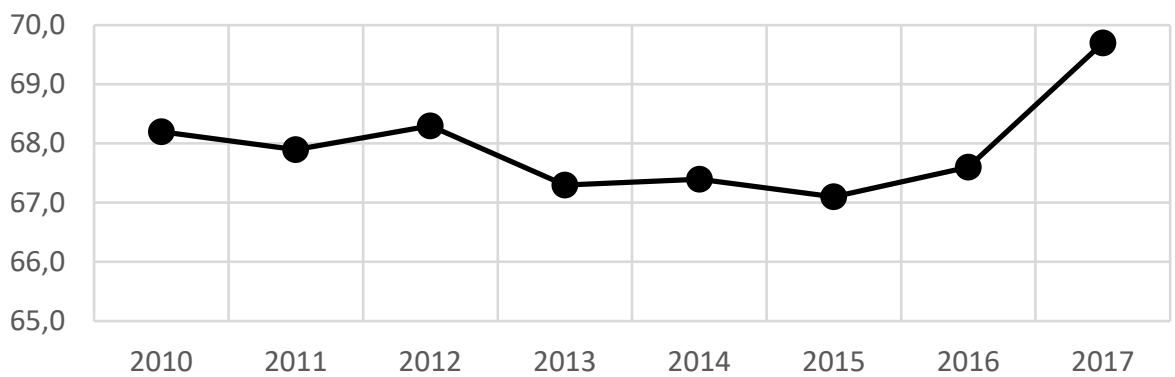

Figure 2. Share of people with good or very good perceived health - the mean values for 28 European countries

Source: own calculations based on data from https://ec.europa.eu/eurostat/web/sdi/main-tables (accessed: 31.08.2019)

In Table 1, we present elements of the statistical analysis of the cross-sectional data presented in EUROSTAT for the $28 \mathrm{EU}$ countries in 2017, i.e., the quartiles and quartile deviations, which characterize the diversity of European countries (for the indicators SDG 3.40 and 3.41, the latest observations were for 2016). The highest level of dispersion was observed for SDG 3.60 Self-reported unmet need for medical examination and care - this indicator reflects the subjective perception of respondents and is affected by differences in the organization of health services in EU countries. The lowest relative dispersion was observed for SDG 3.10 - Life expectancy at birth. It means that most EU countries do not differ much, taking into account this characteristic. We also checked correlations among the indicators. We found that the Pearson correlation coefficient between SDG3.10 and SDG3.40 (death rate due to chronic diseases) was -0.96, so the criteria are strongly linearly correlated. 


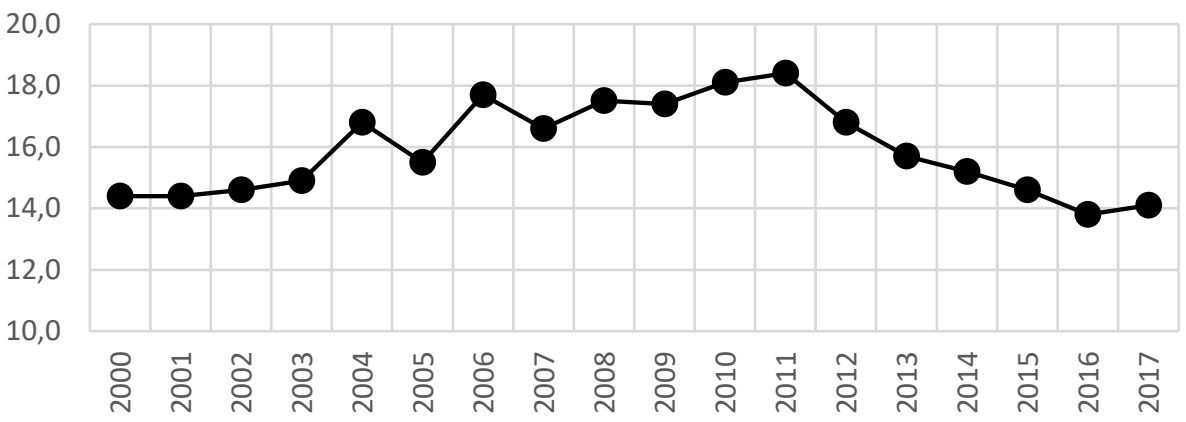

Figure 3. Exposure to air pollution PM2.5 (diameters less than 2.5 micrometers) - the mean values for 28 European countries

Source: own calculations based on data from https://ec.europa.eu/eurostat/web/sdi/main-tables (accessed: 31.08.2019).

Exposure to air pollution PM10 [SDG_11_50]

\section{8 countries}

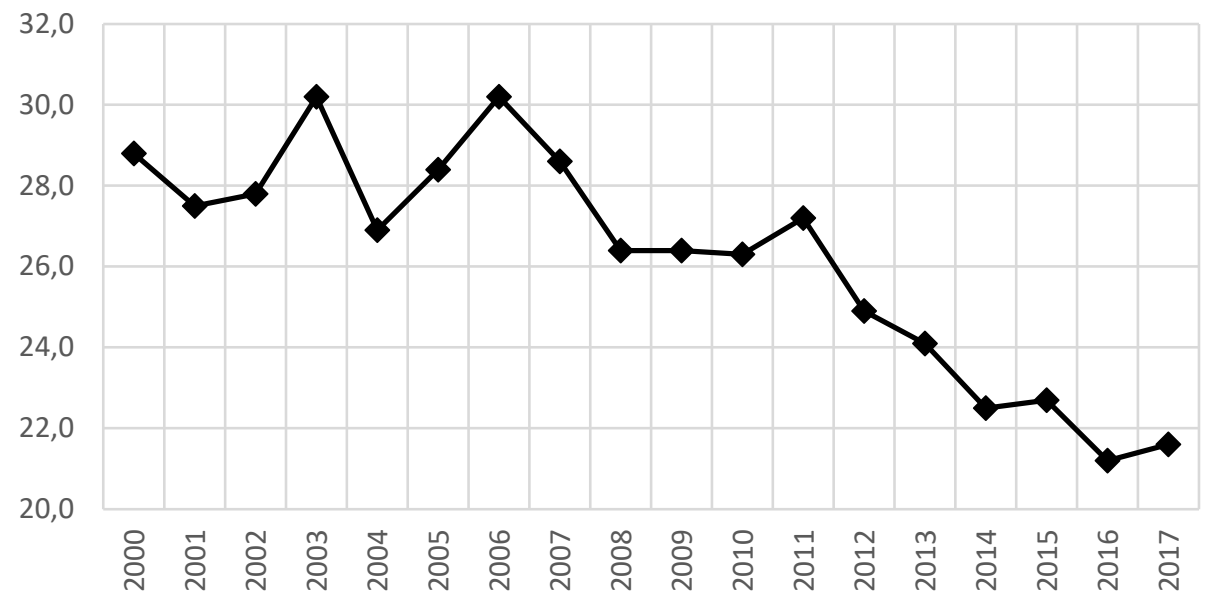

Figure 4. Exposure to air pollution PM10 (diameter less than 10 micrometers) - the mean values for 28 European countries

Source: own calculations based on data from https://ec.europa.eu/eurostat/web/sdi/main-tables (accessed: 31.08.2019). 
Table 1. Statistical characteristics of the Goal 3 indices

\begin{tabular}{|l|c|r|r|r|r|r|r|c|}
\hline Index & $\begin{array}{c}\text { European Union } \\
-28 \text { countries } \\
\text { mean }\end{array}$ & min & Q1 & Median & Q3 & max & $\begin{array}{c}\text { Quartile } \\
\text { deviation }\end{array}$ & $\begin{array}{c}\text { Relative } \\
\text { quartile } \\
\text { deviation }\end{array}$ \\
\hline sdg3.10 & 80.9 & 74.8 & 78.0 & 81.4 & 82.1 & 83.4 & 2.1 & $2.6 \%$ \\
\hline sdg3.20 & 69.7 & 43.9 & 61.7 & 70.3 & 74.4 & 83.3 & 6.4 & $9.1 \%$ \\
\hline sdg3.30 & 26 & 7.0 & 20.8 & 26.5 & 29.0 & 37.0 & 4.1 & $15.6 \%$ \\
\hline sdg3.40 & 119 & 78.7 & 98.8 & 112.7 & 159.3 & 243.7 & 30.3 & $26.9 \%$ \\
\hline sdg3.41 & 2.6 & 0.7 & 1.2 & 1.8 & 3.1 & 10.5 & 1.0 & $54.2 \%$ \\
\hline sdg3.60 & 1.7 & 0.1 & 0.9 & 1.7 & 3.3 & 11.8 & 1.2 & $71.3 \%$ \\
\hline sdg2.10 & 52 & 44.9 & 50.0 & 55.3 & 57.0 & 62.9 & 3.5 & $6.4 \%$ \\
\hline sdg8.60 & 1.68 & 0.5 & 0.9 & 1.9 & 2.6 & 4.5 & 0.8 & $42.2 \%$ \\
\hline sdg11.20 & 17.5 & 8.2 & 12.5 & 15.3 & 18.9 & 26.1 & 3.2 & $21.0 \%$ \\
\hline sdg11.40 & 4.9 & 2.5 & 3.9 & 5.2 & 6.5 & 10.0 & 1.3 & $25.5 \%$ \\
\hline sdg11.50a & 21.6 & 10.0 & 17.3 & 20.4 & 26.1 & 37.3 & 4.4 & $21.6 \%$ \\
\hline sdg11.50b & 14.1 & 4.9 & 11.2 & 12.9 & 19.0 & 23.8 & 3.9 & $30.2 \%$ \\
\hline
\end{tabular}

Source: own calculations; data from https://ec.europa.eu/eurostat/web/sdi/main-tables (accessed: 31.08.2019)

Considering the desirable direction of change for different indicators, we prepared a uni-criteria ranking of EU countries based on data from 2017. These rankings for 12 criteria are presented in Table 2 . The rankings are rated from best to worst, with 1 being the best.

In 2017, life expectancy was the longest in Spain and Italy, at over 83 years. In France, Sweden, Malta, Ireland, Cyprus, and Luxembourg, life expectancy was over 82 years, although it differs between sexes. For Poland, Slovakia, Hungary, Lithuania, Romania, Latvia, and Bulgaria, the statistics show life expectancy below 78 years.

Another index, which expresses the subjective feeling of good health, shows that the best comfort is expressed by citizens of Ireland, Cyprus, Italy, Sweden, and the Netherlands. In the case of Portugal, Latvia, and Lithuania, fewer than $50 \%$ of citizens presented such an opinion.

The lowest smoking prevalence was in Sweden (only 7\% in total). In contrast, more than $30 \%$ of the population over 15 years smoked in Latvia, Croatia, Bulgaria, France, and Greece.

The death rate due to chronic diseases before 65 is the highest for Latvia (10.5 per 100,000), Lithuania, Romania, and Portugal. In other European countries, it is much better. Meanwhile, there were over 200 deaths per 100,000 people from tuberculosis, HIV, and hepatitis in Latvia, Lithuania, Romania, and Hungary. The self-reported, subjective indicator of unmet needs for medical care shows that in Spain, the Netherlands, Malta, Austria, Germany, Luxembourg, and Czechia citizens are content with the medical care they receive - their needs are almost satisfied (only below 1\% report unmet needs). More than 10\% of the population in Greece and Estonia had problems getting help from the country's medical system. 
The share of obese and pre-obese people over 18 exceeds $60 \%$ of the population in Croatia, Finland, Malta, Czechia, and Romania. In all other countries, it is higher than $40 \%$.

The number of people dying in road accidents was highest in Latvia, Poland, Croatia, Bulgaria, and Romania - more than 7 deaths per 100,000 people.

Finally, considering air pollution, extremely high pollution by particulates $<2.5$ (greater than $20 \mu \mathrm{g} / \mathrm{m}^{3}$ ) was observed for Romania, Hungary, Bulgaria, and Poland.

Table 2. Rankings of the EU countries for Goal 3 individual criteria

\begin{tabular}{|c|c|c|c|c|c|c|c|c|c|c|c|c|}
\hline \multirow[b]{2}{*}{ Country } & \multicolumn{12}{|c|}{ Index } \\
\hline & $\begin{array}{l}\text { 울 } \\
\text { ஸ் } \\
\text { b }\end{array}$ & 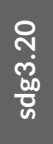 & $\begin{array}{l}\text { 우 } \\
\text { ஸे } \\
\text { চ0 }\end{array}$ &  & 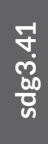 & 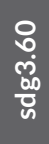 & $\begin{array}{l}\text { 움 } \\
\text { ஸे } \\
\text { চூ }\end{array}$ & 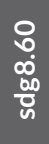 & 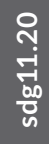 & 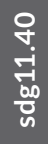 & 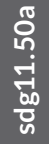 & 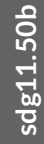 \\
\hline Austria & 10 & 14 & 17 & 12 & 20 & 3 & 8 & 21 & 20 & 12 & 11 & 15 \\
\hline Belgium & 12 & 8 & 3 & 8 & 6 & 16 & 5 & 11 & 15 & 16 & 14 & 13 \\
\hline Bulgaria & 28 & 18 & 26 & 24 & 16 & 16 & 23 & 27 & 4 & 27 & 26 & 24 \\
\hline Croatia & 21 & 22 & 25 & 22 & 22 & 14 & 24 & 22 & 2 & 26 & 25 & 19 \\
\hline Cyprus & 6 & 2 & 17 & 2 & 13 & 12 & 12 & 2 & 17 & 20 & 22 & 16 \\
\hline Czechia & 19 & 21 & 21 & 19 & 4 & 7 & 27 & 12 & 12 & 16 & 17 & 18 \\
\hline Denmark & 17 & 11 & 3 & 13 & 8 & 8 & 4 & 7 & 21 & 3 & 5 & 5 \\
\hline Estonia & 20 & 25 & 9 & 21 & 24 & 28 & 16 & 9 & 1 & 6 & 2 & 2 \\
\hline Finland & 10 & 15 & 7 & 9 & 1 & 24 & 25 & 8 & 7 & 11 & 1 & 1 \\
\hline France & 3 & 16 & 26 & 11 & 15 & 8 & 2 & 23 & 16 & 15 & 10 & 9 \\
\hline Germany & 17 & 19 & 11 & 14 & 13 & 5 & 10 & 5 & 28 & 7 & 8 & 12 \\
\hline Greece & 14 & 10 & 28 & 18 & 12 & 27 & 20 & 10 & 23 & 22 & - & - \\
\hline Hungary & 24 & 23 & 15 & 28 & 18 & 8 & 19 & 18 & 5 & 21 & 20 & 23 \\
\hline Ireland & 6 & 1 & 3 & 6 & 8 & 20 & 22 & 14 & 3 & 5 & 3 & 4 \\
\hline Italy & 2 & 3 & 11 & 3 & 23 & 15 & 1 & 19 & 7 & 18 & 22 & 20 \\
\hline Latvia & 27 & 27 & 24 & 25 & 28 & 26 & 21 & 20 & 13 & 24 & 7 & 14 \\
\hline Lithuania & 25 & 28 & 21 & 26 & 27 & 12 & 18 & 25 & 10 & 22 & 16 & - \\
\hline Luxembourg & 8 & 12 & 8 & 4 & 6 & 5 & 6 & 23 & 24 & 10 & 13 & 7 \\
\hline Malta & 5 & 6 & 10 & 10 & 17 & 3 & 26 & 1 & 26 & 9 & - & - \\
\hline Netherlands & 9 & 5 & 3 & 7 & 1 & 1 & 3 & 3 & 27 & 4 & 11 & 8 \\
\hline Poland & 22 & 24 & 23 & 20 & 18 & 21 & 15 & 16 & 6 & 25 & 24 & 24 \\
\hline Portugal & 12 & 26 & 13 & 17 & 25 & 18 & 13 & 26 & 25 & 19 & 9 & 9 \\
\hline Romania & 26 & 13 & 17 & 27 & 26 & 25 & 28 & 28 & 22 & 28 & 21 & 22 \\
\hline Slovakia & 23 & 17 & 13 & 23 & 8 & 19 & 14 & 16 & 9 & 14 & 18 & 17 \\
\hline Slovenia & 16 & 20 & 17 & 16 & 3 & 23 & 11 & 13 & 11 & 13 & 19 & 21 \\
\hline Spain & 1 & 9 & 15 & 4 & 21 & 1 & 9 & 15 & 14 & 8 & 15 & 11 \\
\hline Sweden & 4 & 4 & 1 & 1 & 5 & 11 & 7 & 6 & 17 & 1 & 4 & 3 \\
\hline UK & 15 & 7 & 2 & 15 & 8 & 21 & 16 & 4 & 19 & 2 & 6 & 6 \\
\hline
\end{tabular}

Source: own calculations; data from https://ec.europa.eu/eurostat/web/sdi/main-tables (accessed: 31.08.2019). 


\section{Multi-criteria rankings of EU countries - Goal 3}

The values of the indicators for each of the NEU countries taken into account ( $N$ in our research was equal to 28 or 25 , depending on data availability) were first normalized in the following way:

- For each of the component indices $f^{(k)}, k=1, \ldots, K$ the range of values were calculated:

$$
R\left(f^{(k)}\right)=\max _{i} f_{i}^{(k)}-\min _{i} f_{i}^{(k)}, i=1, \ldots, N
$$

- If the lowest value of the index was "the best," then the data were transformed in the following way:

$$
f_{i}^{\prime(k)}=\frac{\max _{i} f_{i}^{(k)}-f_{i}^{(k)}}{R\left(f^{(k)}\right)} .
$$

- If the highest value of the index was "the best," then data were transformed in the following way:

$$
f_{i}^{\prime(k)}=\frac{f_{i}^{(k)}-\min _{i} f_{i}^{(k)}}{R\left(f^{(k)}\right)} .
$$

- After normalization, all transformed component indicators were expressed as ascending variables, i.e., higher values denoted better performance, 1 - for the best case, 0 - for the worst.

- In the next step, the component indicators needed to be weighted and aggregated. The rule was to choose equal weights $w_{k}$ for individual indicators ${ }^{15}$, except for the SDG11.50a and SDG11.50b indicators, as they both measure the achievement of the same goal - air pollution. Finally, in the case of 12 criteria, ten indicators were weighted by $1 / 11$ and 2 of them (SDG11.50a and SDG11.50b) by $1 / 22$.

- The multi-criteria indicator of performance, a composite indicator, was defined as the synthetic variable being the weighted average of component indices ${ }^{16}$ :

15 Component weighting is an especially difficult issue, and related in part to the high correlations between component variables. As it is probably impossible to achieve agreement on what the weights should be the simplest choice, equal weights seems to be the best.

16 Multi-criteria index is treated as a linear function of the component indices. 


$$
Q_{i}=\sum_{k=1}^{K} w_{k} f_{i}^{\prime(k)}, i=1, \ldots, N
$$

In the $1^{\text {st }}$ ranking, we excluded indicators measuring air pollution - SDG11.50 - as data for Greece, Lithuania, and Malta were not available in full. Finally, ten criteria were taken into account, and the ranking was prepared for $28 \mathrm{EU}$ countries.

In the $2^{\text {nd }}$ ranking, we excluded Greece, Lithuania, and Malta. Twelve criteria were taken into account, and the ranking was done for $25 \mathrm{EU}$ countries.

Normalization we have used changed the sign of the highest in absolute value correlation coefficient equal $-0,96$ to positive.

We compared our results to the Sachs' group results on global SDG for Goal 3. Their group methodology differs, as first of all, they took into account different criteria:

- Maternal mortality rate (per 100,000 live births) ${ }^{17}$,

- Neonatal mortality rate (per 1,000 live births) ${ }^{18}$,

- Mortality rate under-5 (per 1,000 live births) ${ }^{19}$,

- Incidence of tuberculosis (per 100,000 people),

- HIV prevalence (per 1,000 population),

- Age-standardized death rate due to cardiovascular disease, cancer, diabetes, and chronic respiratory disease in populations age $30-70$ years (per 100,000 people),

- Age-standardized death rate attributable to household air pollution and ambient air pollution (per 100,000 people), source: WHO (2018), year of reference 2012,

- Traffic deaths rate (per 100,000 people),

- Healthy life expectancy at birth (years),

- Adolescent fertility rate (births per 1,000 women aged 15-19),

- Births attended by skilled health personnel (\%),

- Surviving infants who have received $2 \mathrm{WHO}$-recommended vaccines (diphtheria DTP and measles) (\%),

- Universal Health Coverage Tracer Index $(0-100)^{20}$,

- Subjective well-being (average ladder score, 0-10) ${ }^{21}$,

17 The estimated number of women between the age of 15-49 who die from pregnancy-related causes while pregnant, or within 42 days of terminating a pregnancy. Reported source of data: WHO (2018).

18 The number of newborn infants who die before reaching 28 days of age, per 1,000 live births. Reported source of data: UNICEF (2018).

19 The probability that a newborn baby will die before reaching age five. Reported source of data: UNICEF (2018).

20 Coverage of essential health services, as defined by 9 tracer interventions and risk-standardized death rates from 32 causes amenable to personal healthcare. Reported source of data: IMHE (2016) - Institute for Health Metrics and Evaluation.

21 Subjective self-evaluation of life, where respondents are asked to evaluate where they feel they stand on a ladder, where 0 represents the worst possible life and 10 the best possible life. Reported source of data: Gallup World Poll (2018) 
- Gap in life expectancy at birth among regions (years) (OECD Member States) $)^{22}$,

- Gap in self-reported health by income (0-100) (OECD Member States) ${ }^{23}$,

- Daily smokers (\% population age 15+) (OECD Member States).

The second point of difference between our approach and that of Sachs is the treatment of missing data. Constructing their SDG index for Goal 3, in the case of missing data, they used an available data closest in time or used an average value for neighboring countries (Lafortune et al. 2018). The authors checked correlations between goals and also across indicators within goals. They found no signs of collinearities between goals. Nevertheless, they found four cases of the Pearson correlation coefficient exceeding 0.9 among indices of Goal 3. These are found between:

- Maternal mortality rate (per 100,000 live births) \& Mortality rate, under-5 (per 1,000 live births),

- Neonatal mortality rate (per 1,000 live births) \& Mortality rate, under-5 (per 1,000 live births),

- Maternal mortality rate (per 100,000 live births) \& Healthy Life Expectancy at birth (years),

- Healthy Life Expectancy at birth (years) \& Mortality rate, under-5 (per 1,000 live births).

The arguments given by authors for not removing highly correlated variables from the construction of the indicator for Goal 3 were the following: "(i) we want to present as much data as possible, and each indicator has distinct policy implications, (ii) the purpose of the SDG Index is not to model SDG achievement, but to track progress, (iii) each indicator is supported by one or more expert communities" (Lafortune et al. 2018, p. 25). We share these arguments in this work. The data used to develop Sachs' global SDG Index were censored at the bottom 2.5 percentile before being normalized. After normalization, the value of 0 denotes the worst performance and 100 describes the technical optimum, where the level of the technical optimum depends on SDG targets formulated eventually or the average of the top 5 performers (Lafortune et al. 2018, p. 11). The aggregation for the Sachs SDG Index is done in two steps $^{24}$ : normalized variables are combined for each SDG and then aggregated across goals using the standard constant-elasticity of substitution (CES) function. For our purposes, we used the published results for the Goal 3 sub-index (Sachs et al. 2018) for EU countries presented in Table 3.

22 Difference between maximum and minimum life expectancy at birth among different regions of the country.

23 Difference between self-reported health status by income level between first and fifth quintile.

24 Sachs et al. (2017, pp. 44-46). 
Table 3. Multi-criteria rankings of EU countries - Goal 3

\begin{tabular}{|c|c|c|c|c|c|c|}
\hline Country & $\begin{array}{c}\text { synthetic } \\
\text { variable } \\
\text { in } 1^{\text {st }} \text { ranking }\end{array}$ & $\begin{array}{l}\text { position } \\
\text { in } 1^{\text {st }} \text { ranking }\end{array}$ & $\begin{array}{c}\text { synthetic } \\
\text { variable } \\
\text { in } 2^{\text {nd }} \text { ranking }\end{array}$ & $\begin{array}{l}\text { position } \\
\text { in } 2^{\text {nd }} \text { ranking }\end{array}$ & $\begin{array}{l}\text { Sachs' } \\
\text { score }\end{array}$ & $\begin{array}{c}\text { Sachs' } \\
\text { ranking }\end{array}$ \\
\hline Austria & 0.675694 & 12 & 0.667036 & 14 & 93.7 & 9 \\
\hline Belgium & 0.75212 & 6 & 0.738126 & 6 & 93.1 & 11 \\
\hline Bulgaria & 0.401247 & 25 & 0.362005 & 23 & 80.1 & 28 \\
\hline Croatia & 0.475063 & 24 & 0.444714 & 22 & 86.1 & 23 \\
\hline Cyprus & 0.735959 & 9 & 0.704164 & 11 & 91.5 & 17 \\
\hline Czechia & 0.583359 & 18 & 0.564316 & 17 & 91.6 & 16 \\
\hline Denmark & 0.778628 & 4 & 0.779618 & 4 & 95.1 & 5 \\
\hline Estonia & 0.514865 & 20 & 0.556638 & 18 & 88.7 & 20 \\
\hline Finland & 0.710317 & 11 & 0.736887 & 7 & 96.5 & 2 \\
\hline France & 0.672547 & 13 & 0.667674 & 12 & 92.9 & 12 \\
\hline Germany & 0.668779 & 15 & 0.667293 & 13 & 94.1 & 7 \\
\hline Greece & 0.52752 & 19 & 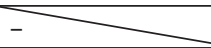 & 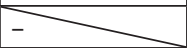 & 89.2 & 19 \\
\hline Hungary & 0.489703 & 23 & 0.468898 & 21 & 85.6 & 24 \\
\hline Ireland & 0.788836 & 3 & 0.79889 & 2 & 94.5 & 6 \\
\hline Italy & 0.754382 & 5 & 0.709103 & 9 & 92.4 & 13 \\
\hline Latvia & 0.277151 & 27 & 0.307776 & 24 & 84.2 & 26 \\
\hline Lithuania & 0.356025 & 26 & - & 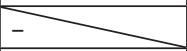 & 85.3 & 25 \\
\hline Luxembourg & 0.71311 & 10 & 0.706108 & 10 & 95.3 & 4 \\
\hline Malta & 0.668834 & 14 & ( &  & 92.0 & 14 \\
\hline Netherlands & 0.79151 & 2 & 0.780372 & 3 & 95.4 & 3 \\
\hline Poland & 0.513932 & 21 & 0.474144 & 20 & 87.7 & 21 \\
\hline Portugal & 0.495464 & 22 & 0.508636 & 19 & 90.9 & 18 \\
\hline Romania & 0.251356 & 28 & 0.252084 & 25 & 81.3 & 27 \\
\hline Slovakia & 0.584522 & 17 & 0.567351 & 16 & 87.5 & 22 \\
\hline Slovenia & 0.668134 & 16 & 0.636908 & 15 & 91.8 & 15 \\
\hline Spain & 0.742381 & 7 & 0.727702 & 8 & 93.8 & 8 \\
\hline Sweden & 0.870838 & 1 & 0.880102 & 1 & 96.7 & 1 \\
\hline UK & 0.739549 & 8 & 0.742292 & 5 & 93.3 & 10 \\
\hline
\end{tabular}

Source: $1^{\text {st }}$ and $2^{\text {nd }}$ rankings results: own calculations. The results for Sachs' score and ranking are presented for comparison following Sachs et al. (2018).

We found that correlation between the synthetic variable in our $1^{\text {st }}$ ranking (without the two indices of air-pollution I11) with Sachs' score is high - the Pearson correlation coefficient is equal to 0.9122 . Sweden has the best position in all rankings, followed by the Netherlands, Denmark, and Ireland. Comparing our two rankings with Sachs' score, we found that it ranks Finland much higher, in $2^{\text {nd }}$ place. The final positions in our rankings are occupied by Eastern European countries: Romania, Latvia, Lithuania, and Bulgaria. In the group second from the end of the list, we can find other Eastern European countries, as well as Portugal and Greece. 




- synthetic variable $1^{\text {st }}$ ranking $\quad$ synthetic variable $2^{\text {nd }}$ ranking $\quad$ Sachs' score

Figure 5. Multi-criteria analysis results for 28 EU countries for Goal 3: synthetic variables for the rankings $1^{\text {st }}, 2^{\text {nd }}$, and also Sachs' score values divided by 100 . The ordering of countries is based on descending values of the synthetic variable for the $1^{\text {st }}$ ranking.

Source: own calculations.

\section{Conclusions}

Our research aimed to compare the situation in European Union countries from the point of view of how far they are from the targets of the 2030 Agenda for Sustainable Development formulated for Goal 3 - Ensure healthy lives and promote well-being for all at all ages. The data and choice of indices we used were taken from the EUROSTAT database. The main result of the multi-criteria analysis is that the closest to these targets are Sweden, the Netherlands, Ireland, and Denmark. The worst are Romania, Latvia, Lithuania, and Bulgaria. The group of countries second from bottom contains Poland, Portugal, and Hungary, while the situation in Estonia and Greece is slightly better.

The optimistic conclusion from our research is the increasing life expectancy in EU countries; in 2017, it was 81.6 years. Nevertheless, recently we have observed that the rate of this increase is declining. The share of the population with good health is at a moderate level $-70 \%$. We observe very high diversification of countries regarding unmet needs for medical examinations and care - the quartile deviation is $71.3 \%$. It is the symptom of many unsolved systemic problems in health care organizations. The data about air pollution are worrying, and achieving the Agenda targets in this area are at risk. 


\section{References}

Document of United Nations Department of Economic and Social Affairs (UN DESA), https://www.un.org/development/desa/disabilities/envision2030-goal3.html (accessed: 31.08.2019).

Lafortune, G., Fuller, G., Moreno, J., Schmidt-Traub, G., Kroll, Ch. (2018), SDG Index and Dashboards. Detailed Methodological paper, available at: https://github.com /sdsna/2018GlobalIndex/raw/master/2018GlobalIndexMethodology.pdf (accessed: 31.08.2019).

McGillivray, M., Noorbakhsh, F. (2004), Composite Indices of Human Well-being. Past, Present, and Future, United Nations University, Wider World Institute for Development Economic Research, Research Paper No. 2004/63.

OECD (2017), How's Life? 2017: Measuring Well-being, OECD Publishing, Paris, https:// doi.org/10.1787/how_life-2017-en (accessed: 31.08.2019).

Sachs, J., Schmidt-Traub, G., Kroll, C., Durand-Delacre, D., Teksoz, K. (2017), SDG Index and Dashboards Report 2017, New York: Bertelsmann Stiftung and Sustainable Development Solutions Network (SDSN).

Sachs, J., Schmidt-Traub, G., Kroll, C., Lafortune, G., Fuller, G. (2018), SDG Index and Dashboards Report 2018, New York: Bertelsmann.

Sustainable development in the European Union. Monitoring report on progress towards the SDGs in an EU context, 2019 edition, Luxembourg: Publications Office of the European Union, 2019.

Transforming our world: the 2030 Agenda for Sustainable Development, Resolution adopted by the General Assembly of United Nations on 25 September 2015, https:// www.un.org/ga/search/view_doc.asp?symbol=A/RES/70/1\&Lang=E. (accessed: 31.08.2019).

https://ec.europa.eu/eurostat/web/sdi/main-tables. (accessed: 31.08.2019).

https://www.un.org/sustainabledevelopment/health/ (accessed: 31.08.2019).

https://www.un.org/sustainabledevelopment/sustainable-development-goals/ (accessed: 31.08.2019).

UNICEF (2018): https://data.unicef.org/ (accessed: 31.08.2019).

WHO (2018): https://www.who.int/gho/publications/world_health_statistics/2018/en/ (accessed: 31.08.2019.

\section{Streszczenie}

\section{Realizacja celu zrównoważonego rozwoju: „Dobre zdrowie i jakość życia" w krajach Unii Europejskiej w roku 2017}

We wrześniu 2015 r., Zgromadzenie Narodowe ONZ przyjęło dokument: "Przekształcanie naszego świata: Agenda na Rzecz Zrównoważonego Rozwoju - 2030". Zawarto w nim 17 Celów Zrównoważonego Rozwoju (SDGs). Jednym z nich jest Cel 3., zdefiniowany w następujący sposób: Zapewnić zdrowe życie oraz promować dobrobyt dla wszystkich ludzi w każdym wieku. W niniejszej pracy przeanalizowano 
12 wskaźników proponowanych przez EUROSTAT dla celów pomiaru poziomu realizacji tego celu. Pokazano dynamikę wartości wskaźników dla Unii Europejskiej na przestrzeni lat 2002-2017. Przeprowadzono porównania dla 28 krajów Unii Europejskiej dla roku 2017 wykorzystując metody jedno- i wielowymiarowej analizy statystycznej. Zaprezentowano rankingi pokazujące różną sytuację krajów Unii Europejskiej na drodze do osiągnięcia zdrowego życia i dobrobytu swoich obywateli. Wyniki zostały porównane z sub-indeksem globalnym SDG dla Celu 3., opracowanym przez Sachs i in. (2018).

Słowa kluczowe: cele zrównoważonego rozwoju, SDG, rankingi wielokryterialne, zdrowie i dobrobyt 